\title{
O MESTRE E O APRENDIZ COMO IGUAIS: A POTÊNCIA DA VONTADE E DA INTELIGÊNCIA HUMANA EM RANCIÈRE
}

\author{
Silvana Aparecida Bretas ${ }^{1}$ \\ Crislaine Santana Cruz ${ }^{2}$
}

\section{RESUMO}

Este artigo tenciona analisar quem são aprendiz e mestre segundo a obra $O$ Mestre Ignorante (2013) de autoria do filósofo Jacques Rancière. Procura entender que papéis esses sujeitos exercem de acordo com o Ensino Universal que é apregoado na obra, cuja ideia fundamental é defender a igualdade intelectual entre mestre e discípulos e, consequentemente, pôr em questão o mestre e suas explicações. Buscou-se verificar reflexivamente os papéis atribuídos aos dois sujeitos mais importantes no processo de ensino-aprendizagem dentro dos limites da obra em estudo, além de tomar conhecimento de conceitos histórico-filosóficos presentes na obra e contribuir para o enriquecimento da discussão sobre a educação e, mais especificamente, sobre a prática pedagógica. Trata-se de pesquisa qualitativa, de abordagem bibliográfica onde a metodologia envolveu o levantamento de comentadores relevantes em relação à obra e a seu autor, da relação vida e obra, de seu contexto sócio histórico e, finalmente, a leitura crítica. Ao defender que a igualdade entre as inteligências do professor e do aluno deve ser tomadas como ponto de partida, e não de chegada, do processo de ensino-aprendizagem, Rancière ainda defende que essa hipótese depende da ação dos homens que, individual ou coletivamente, devem criar modos de verificá-la.

Palavras-chaves: Ensino Universal; Igualdade; Mestre; Aprendiz; Explicação; Pensamento Pedagógico

\section{MASTER AND APPRENTICE AS EQUAL : THE POWER OF WILL AND HUMAN INTELIGÊNCIA IN RANCIÈRE}

\begin{abstract}
This article intends to analyze who are apprentice and master after the work The Master Ignorant (2013) authored by philosopher Jacques Rancière. Seeks to understand these subjects roles exercised according to the universal teaching that is proclaimed in the work, whose basic idea is to defend the intellectual equality between master and disciples and thus to question the master and his explanations. We attempted to verify reflexively the roles of the two subjects most important in the teaching-learning process within the limits of the work under study, as well as become aware of historical and philosophical concepts present in the work and contribute to enriching the discussion on education and more specifically on the pedagogical practice. It is a qualitative research, bibliographic approach where the methodology involved the collection of relevant commentators to work in the respect life and work, the historical partner in work and critical reading context. In arguing that the equality of the intelligences of the teacher and the student should be taken as a starting point, not the arrival of the process of teaching and learning, Rancière argues that this hypothesis depends on the action of men who, individually or collectively, should create ways to check it out.

Keywords: Universal Teaching; Equality; Master; Apprentice; Explanation; Pedagogical thinking.
\end{abstract}


Este trabalho se insere no campo de estudos sobre fenômenos educacionais, na perspectiva histórica. $\mathrm{O}$ tema $\mathrm{O}$ mestre e o aprendiz como iguais: a potência da vontade e da inteligência humana em Rancière, surgiu a partir de levantamentos relativos à obra $O$ mestre ignorante (2013) escrita em 1987. Nela o filósofo Jacques Rancière resgata a atraente trajetória de Joseph Jacotot, um professor francês que em 1818 viveu uma experiência educativa que mudou radicalmente seu método de ensino; a partir de tal experiência Jacotot passou a acastelar a igualdade das inteligências humanas, afirmando que se pode ensinar qualquer coisa, mesmo sendo um total ignorante no assunto, para isso, é exigido somente que aluno e professor sejam emancipados. O mestre deve levar o aprendiz a conduzir-se porsua própria inteligência para aprender. Assim, o aprendiz pode tanto quanto pode o mestre, essa é a ideia central do Ensino Universal anunciado por Jacotot e seus loucos partidários.

Em seu estudo, OLIVEIRA (s/d, p. 34) salienta que a pesquisa só acontece se temos algo singular a responder. $\mathrm{O}$ objeto de pesquisa deve nos parecer obscuro e curioso o bastante para que queiramos desvendá-lo. $O$ mestre ignorante (2013) suscita questões fundamentais e ao mesmo tempo ordinárias, como a relação mestre/aprendiz que ao nosso olhar parece tão bem deliberada. $\mathrm{O}$ autor nos incita a refletir sobre a educação e as bases nas quais está alicerçada. O Ensino Universal, defendido na obra, trata-se mesmo de uma revolução que se iniciou em 1818 e que ainda tende a despontar. Essa é a razão pela qual entendemos a obra de Rancière como um importante contributo à pedagogia.

Sempre que acontece uma revolução há que se definirem novos contornos, novas conjunturas sociais de acordo com as conquistas. Foi assim com a Revolução Industrial, século XVIII e com a Revolução Feminista, século XIX, e pensamos que a revolução na educação, iniciada por Jacotot em 1818, já esperou tempo demais por seus efeitos. Dessa forma, pretendemos contribuir para com esta, acreditando que a educação contemporânea necessita voltar-se para sua historicidade e repensar reflexivamente no que mudou e no que ainda permanece entorpecido em sua trajetória.

Dentro desse contexto, a pesquisa aqui desenvolvida pretende analisar as ideias presentes na obra de Rancière, a fim de conhecer quem é o mestre, quem é o aluno na sua perspectiva, e quais os papéis definidos para esses sujeitos dentro do Ensino Universal. A pesquisa focar-se-á fundamentalmente nesses elementos para explorar a obra do filósofo.

Joseph Jacotot afirma que para aprender basta que se tenha vontade, deste modo a inteligência nada mais é que servidora da vontade do indivíduo, ela está igualmente em todos, mestres ou alunos, simplesmente por serem homens.

Na obra $O$ mestre ignorante (2013), o filósofo Jacques Rancière retoma o ideal do Ensino Universal defendido por Jacotot e revela que se pode aprender qualquer coisa sem o mestre explicador. Essa boa nova de acordo com o seu criador deveria ser levada a todos, de maneira particular aos pobres, uma vez que sofrem mais com a teoria da desigualdade das inteligências, intimamente ligada a divisão de classes e a dominação de umas pela outras.

Jacotot coloca todos num mesmo nível, professor e aluno, adulto e criança, rico e pobre, homem e mulher; todos possuem em si a potência da inteligência, esta só se diferencia de um para o outro nos seus efeitos, na sua manifestação.

Visto que a figura do professor explicador é colocada em cheque, bem como a posição do aluno frente ao conhecimento, fazem-se imperativas as seguintes questões: quem são aprendiz e mestre segundo Rancière? Que papéis esses sujeitos exercem de acordo com o Ensino Universal, proposto na obra?

Para dar resposta a tais questionamentos pretendemos focalizar nossa análise no processo pelo qual o Ensino Universal se constitui na obra de Rancière, considerando o 
conceito de emancipação, definido pelo autor como "a consciência daquilo que pode uma inteligência, quando ela se considera como igual a qualquer outra e considera, da mesma forma, qualquer outra inteligência como igual a si". (RANCIÈRE, 2013, p. 64).

Como objetivo geral do presente artigo tem-se: verificar reflexivamente os papéis atribuídos aos dois sujeitos mais importantes no processo de ensino-aprendizagem, professor e aluno dentro dos limites estabelecidos na obra em estudo. Além desse, pretendemos tomar conhecimento de conceitos históricos-filosóficos presentes na obra; apontar as características da educação emancipadora de Jacques Rancière; contribuir para o enriquecimento da discussão sobre a educação e mais especificamente sobre a prática pedagógica.

O objeto escolhido para estudo não tem a pretensão de transformar a educação, pretensão desmedida a um artigo, mas não se esquiva de procurar contribuir na reflexão das bases que a norteiam e a sustentam. Esse objeto requer um tratamento metodológico específico, como bem define Lucini (s/d, p. 22): [...] "Trata-se de contemplar o objeto que reivindica o método e o método que define e redefine o objeto".

Trata-se de uma pesquisa de abordagem qualitativa com enfoque bibliográfico, cujas análises compõem um universo heterogêneo de métodos e técnicas (GATTI, 2002, p. 27). Nessa perspectiva, a metodologia baseia-se em levantamento de literatura relevante ao tema do objeto estudado, estudo da relação vida e obra do autor em questão, estudo do contexto sócio histórico da obra e leitura crítica. Fizemos a escolha da abordagem temática da obra em estudo baseando-nos na entrevista cedida por Rancière a Revista Educação $e$ Sociedade (VERMEREN, CORNU e BENVENUTO, 2003) na qual os entrevistadores identificam cinco teses/lições presentes na obra. Nos dedicamos as três teses/lições em particular, por referirem-se especificamente ao tema escolhido para este artigo.

$\mathrm{Na}$ obra $O$ Mestre ignorante: Cinco lições sobre emancipação intelectual de Jacques Rancière (2013), o filósofo compartilha com seus leitores a trajetória de um personagem inusitado, Joseph Jacotot. Pedagogo francês que, em 1818, anunciou em alto e bom tom a hipótese que poderia mudar os rumos do ensino e aprendizagem da pedagogia moderna, se não fosse uma voz solitária. A ideia de Joseph Jacotot não ganhou respaldo entre as tantas teorias que falam a respeito da pedagogia, talvez porque ela difere de todas elas, talvez porque seja tão única e espantosa. O fato é que os historiadores da educação e até mesmo os próprios pedagogos não se interessaram e, portanto, não puderam ouvir sobre o ato experimental da prática educativa vivenciada por Jacotot em seu tempo de exílio nos distantes Países Baixos (1818 - 1830), quando os alunos não podiam entender o mestre e nem o mestre entender os alunos pelo fato de ambos dominarem idiomas diferentes, os primeiros o holandês e o segundo o francês. Felizmente, por obra do acaso, o filosofo da arte, da política e da estética, Rancière, se depara com alguns escritos fragmentários sobre a experiência educativa de Joseph Jacotot e, então, se dispõe a desvendar seu sentido e significado para a educação na contemporaneidade.

A obra a que nos propusemos decifrar apresenta-se, ao nosso olhar, como um objeto peculiar, instigante e desafiador no que se refere ao seu enquadramento aos padrões científicos exigidos na academia. O desafio ganha proporções ainda mais amplas quando consideramos a importância de se discutir ideias como as de Jacotot e Rancière dentro do centro da formação docente, especialmente, no interior da universidade. Queremos deixar claro, entretanto, que não pretendemos com isto, capturar o sentido da obra de Rancière, mas tão somente apresentar a nossa interpretação pessoal da obra, afinal isso é tudo o que se pode fazer quando se está diante de um trabalho intelectual que escapa a todas as teias científicas e acadêmicas. Por isso, concordamos com o professor Carlos Skliar quando declara que: 
[...] o livro de Rancière não deveria ser um objeto de compreensão, no sentido que a moral e/ou a ética o pretendem. Deve ser, isso sim, olhado, tocado, sentido. Assim como a aventura intelectual de Jacotot e como a sua própria pedagogia. Sua leitura não poderá ser uma rápida tradução em discurso pedagógico, em reforma educativa etérea, ou em simples mudança curricular (SKLIAR, 2003, p. 230).

Deverá ser acima de tudo uma inspiração e uma reflexão para que se realize a emancipação intelectual em nosso meio.

Sendo Rancière um filósofo, sua obra também o é, e podemos caracterizar sua escrita na trama de um texto de cunho filosófico que se utiliza de uma linguagem literária denominada aforismo que, segundo o E-Dicionário de termos literários (2014), é um estilo de escrita que pode, em análise linguística, revelar certas estratégias lexicais, sintáticas e semânticas. Em outras palavras, considera-se importante, além do conteúdo, a forma de expressão que deve ser curta, concisa e, especialmente, apresentar um sentido figurado de grande expressividade estilística. Além disso, o recurso frequente a palavras polissêmicas, a sinônimos, a antônimos, a perguntas retóricas, torna-o um instrumento clássico do poder do discurso. Pode aparecer como afirmação política, filosófica, moral, apresentando um ideal de sabedoria (PIRES, s/d).

Rancière emprega em seu texto esse estilo literário que, conforme nossa compreensão, caracteriza a sua forma de escrever que envolve o leitor tão completamente que pouco lhe sobra para racionalizar e sintetizar suas ideias. Também para Skliar, a linguagem empregada nos textos do autor, remete "o leitor a uma leitura diferente, que difere de outras leituras e de outras escritas" (SKLIAR, 2003, p. 230).

Vale dizer, que o cuidado estético com a escrita não está presente apenas na obra $O$ mestre ignorante (2013), mas, sobretudo, na constituição de sua intelectualidade traduzida, mais precisamente, nas reflexões sobre a política e estética no sofisticado campo filosófico.

Jacques Rancière ${ }^{3}$ é um filósofo francês nascido em Argel em 1940, ano em que ocorreu a famosa Batalha da França quando o país foi invadido pela Alemanha Nazista. É professor emérito da Universidade de Paris VIII e um dos pensadores mais influentes nas discussões artísticas da contemporaneidade, por isso, seus críticos têm o definido em diferentes pontos como um filósofo, um crítico literário, um teórico de arte e um marxista. Dentre sua vasta obra ainda em construção, o livro objeto de estudo do presente artigo, teve sua primeira publicação em 1987 e, é o único escrito do autor a tratar sobre o tema da educação. Importante ressaltar que essa discussão centra-se mais especificamente na concepção de igualdade nos processos educativos. O filósofo francês entende que entre as pedagogias modernas, a de Jacotot é, sem sombra de dúvida, a que mais vivamente realiza a igualdade entre o mestre e os alunos. Mas como se deu o encontro de Rancière com Jacotot? Por que um filósofo que dedica sua abra a discutir arte, política e crítica literária se inquieta e se interessa por uma prática educativa? O que mais lhe chamou atenção? Sem a pretensão de responder a esses questionamentos nos dedicamos a tentar compreender a relação de Jacques Rancière com a pedagogia de Joseph Jacotot.

Em entrevista concedida a Revista Educação e Sociedade (VERMEREN, CORNU e BENVENUTO, 2003, p. 187) Rancière relata que o motivo que levou a escrever esta obra foi um encontro individual com a figura de Joseph Jacotot enquanto ainda escrevia $A$ noite dos proletários (1981). De início, leu textos que continham alguns pontos isolados da trajetória desse professor e sobre algumas formas de aprendizagem intelectual inspirada por suas ideias, e sempre no sentido de uma experiência de emancipação intelectual.

Esse ponto de partida foi suficiente para que Jaques Rancière tomasse a experiência educacional anárquica de Jacotot para dar origem à obra $O$ Mestre ignorante e, com ela, 
fomentar as controvérsias existentes entre o sociologismo progressista de Pierre Bourdieu e os defensores do pensamento educacional republicano dos anos 1980 na França. Segundo o sociologismo, a escola burguesa, inserida na sociedade capitalista, não realiza outra prática educativa senão reproduzir as relações sociais desiguais e injustas através do ato de ensinar como também de sua estrutura burocrática e institucional. Portanto, só seria possível uma escola igualitária se houvesse a superação da sociedade de classe ${ }^{4}$. Esse pensamento propunha, então que se criassem formas de adaptação do saber às populações desfavorecidas. Já os republicanos defendiam que somente a difusão indiferenciada do saber poderia ser instrumento de igualdade. Ora, as ideias de Joseph Jacotot, agora proferidas por Rancière, se opunham a esses dois pensamentos, pois, para ambos, o saber é que se faz instrumento de igualdade, não a organização do currículo escolar. A proposta de emancipação intelectual de Jacotot, então, se punha como questionamento a esses dois modelos comuns entre si.

Rancière viu ai uma boa oportunidade para polemizar esse debate na medida em que passa a discorrer sobre a relação de igualdade na intimidade entre o professor e o aluno, ou seja, seres inteligentes e, por isso, participantes de uma experiência de ensino e aprendizagem em condição de igualdade. Mas, para levantar essa polêmica Rancière expõe como realiza o seu projeto: empresta sua linguagem aforística à experiência de Jacotot, a partir de sua própria base de reflexão, para criticar à concepção de igualdade tanto do sociologismo quanto do republicanismo.

Na mesma entrevista (op.cit., p. 187) Rancière ressalta que todo seu trabalho teórico esteve associado à tentativa de falar por meio das palavras dos outros:

\begin{abstract}
Quanto à proximidade entre as teses de Jacotot e as minhas: é evidente que todo meu trabalho teórico esteve associado à tentativa de falar por meio das palavras dos outros, de fazer falar diferentemente as palavras dos outros, refraseando-as, recolocando-as em cena. Assim, o interesse desse livro está em uma certa arte, em um exercício de refrasear que me permitiu projetar no debate intelectual dos anos 80 todo um léxico e uma retórica inteiramente datados e, inversamente, emprestar a Jacotot, como se estivessem na base de sua reflexão, razões que derivavam da crítica ao pensamento sobre a igualdade, tal como ele se produzia na França dos anos de 1980. Tratava-se de inserir o debate contemporâneo em uma perspectiva bem mais antiga da questão da igualdade e, portanto, de suprimir a diferença; e, ao mesmo tempo, de fazer valer, para essa atualidade, a estranheza radical da posição teórica de Jacotot, sua inatualidade em relação a seu próprio tempo - o tempo das origens da grande cruzada pela "instrução do povo", à qual ele opôs a emancipação intelectual. (VERMEREN, CORNU e BENVENUTO, 2003, op.cit., 187).
\end{abstract}

O mestre ignorante é, portanto, um exercício de refrasear, recolocar e, ao mesmo tempo, de demonstrar a antiguidade e atualidade do debate sobre a (des)igualdade entre quem ensina e quem aprende. Mais do que isso, a obra em questão provoca a reflexão para o equívoco de pensar que a educação são doses de ensino ao chamado ignorante ou não educado. A igualdade, no caso, não se trata de igualdade social ou cultural, mas, sobretudo da igualdade intelectual entre o mestre e o aprendiz. As palavras/lições de Jacotot experienciadas ainda no século XIX, são projetadas no debate intelectual contemporâneo por força de Rancière, portanto, precisamos perceber o personagem e o filósofo como dois seres imbricados, pois compartilham que a emancipação se faz, antes de tudo, a partir da igualdade intelectual. Jacotot fala ao século XX pelas palavras de Rancière e, esse, reflete sobre a emancipação na contemporaneidade pela experiência de Jacotot no século XIX.

Ao pensarmos em como abordar a obra de Rancière, decidimos escrever aquilo que íamos desvelando a cada capítulo lido e refletido, porque cada um aprofunda a Revista HISTEDBR On-line, Campinas, $n^{o}$ 63, p. 210-232, jun2015 - ISSN: 1676-2584 
compreensão das diferentes teses/lições sobre emancipação intelectual deixadas pelo modesto professor Joseph Jacotot. Ainda na entrevista concedida a Revista Educação $e$ Sociedade (VERMEREN, CORNU e BENVENUTO, 2003) os entrevistadores de Rancière identificam essas teses/lições como sendo: 1) a ignorância do mestre é a desigualdade; 2) o princípio, a igualdade, é um axioma a ser verificado; 3) a emancipação supõe um funcionamento igual e universal das inteligências; 4) a lógica da emancipação nunca trata, em definitivo, senão com relações individuais e, por fim, 5) A lógica da emancipação não é - não pode ser - um sistema escolar, ou uma empreitada cultural (VERMEREN, CORNU e BENVENUTO, 2003).

Comporemos o estudo da obra do autor guiando-nos pelas três primeiras teses/lições identificadas pelos entrevistadores da Revista Educação e Sociedade (op.cit.,2003), por percebê-las também na obra e por considerá-las suficientes às questões que nos motivaram a realizar esse estudo, sendo assim, não trabalharemos com as duas últimas teses/lições por não corresponderem diretamente as nossas inquietações a respeito da obra, embora, não neguemos sua relevância para o debate sobre a educação.

Para que se possa conhecer a ideias de Joseph Jacotot faz-se imperativo conhecer sua trajetória e perceber em que ponto as coisas começaram a ganhar um novo sentido para este professor, que ao se autodeclarar um mestre ignorante, travou o início de uma guerra contra as pedagogias estabelecidas que se autoproclamavam redentoras da ignorância, da barbárie e da anti-civilidade.

Jacotot, até 1818, era um pedagogo como qualquer outro que se prese e queria ensinar da melhor forma possível o seu aluno ou, pelo menos, era assim que se reconhecia ${ }^{5}$. Viveu no momento crucial onde a França, a partir da Revolução Iluminista (1789-1799), pensava a criação de um sistema nacional de educação que pudesse garantir a criança do povo uma adequada preparação para a vida. Com a queda de Napoleão, a monarquia Bourbon foi restaurada, Joseph Jacotot, por ser um revolucionário, teve de se exilar nos Países-Baixos, é nesse ponto que sua aventura intelectual se inicia.

No país onde fora acolhido, Joseph Jacotot ganhou um posto de professor em que trabalhava por meio período, cujos estudantes que vieram ouvir suas explicações ignoravam o francês. O modesto professor, por sua vez, ignorava o holandês e, assim, sem uma língua em comum com qual pudesse efetivar a comunicação entre eles, o professor tentou, como uma ação de improviso, dessas que todo professor mais ou menos experiente tem de tomar em certos momentos, estabelecer um laço mínimo com seus alunos através de uma edição bilíngue de Telêmaco ${ }^{6}$. Com o auxílio de um intérprete Jacotot indicou a leitura aos estudantes e depois de algum tempo solicitou-lhes que escrevessem em francês tudo o que tinham lido até o momento (op. cit.,17). A surpresa fica por conta dos textos escritos pelos alunos. Sem explicações quanto à estrutura da língua francesa, suas flexões, radicais e vocabulário; amparados, tão-somente, pela tradução do texto, os alunos haviam escrito textos tão bons quanto poderiam fazer muitos franceses. É a partir dessa experiência que Jacotot começa a questionar a necessidade das explicações para ensinar.

Se os seus alunos haviam se saído tão bem sem que recebessem nenhuma explicação daquilo que até então era desconhecido, não podiam todos os homens aprender da mesma forma? E, afinal, para quê, ou para quem a explicação se faz necessária?

Jacotot passa então a acastelar a hipótese de que a virtude mais importante de um professor é a sua ignorância. Essa declaração causou grande espanto em sua época, muito embora, suspeitamos que ainda tende a causar grandes e alarmantes espantos nos meios educacionais e pedagógicos contemporâneos, onde o conhecimento do professor é sempre tão valorizado e enaltecido. Esse espanto é compreensível, pois quando Jacotot defende a ignorância do professor como sua maior virtude parece, à primeira vista, que está 
desvalorizando seu conhecimento pedagógico e, consequentemente, sua formação acadêmica, seus métodos e as teorias que regem sua prática. E não só isso, parece desprezar também seu esforço pedagógico para fazer com que o aluno progrida e saia da ignorância. Mas, se olharmos mais profundamente suas ideias e colocações, veremos que é exatamente disso que se trata.

Mas o que significa ser um mestre ignorante quando sua tarefa precípua é justamente "salvar" o aluno da ignorância, redimindo-o de sua quase condição de bárbaro? Como dois ignorantes, mestre e discípulo, poderiam responder às exigências de uma sociedade livre, igualitária e fraterna tal como se queria entender os políticos e intelectuais do Iluminismo francês?

A primeira tese/lição a que nos propomos analisar defende que a ignorância do mestre é a da desigualdade, no texto Jacques Rancière: education, truth, emancipation (CHARLES, BIESTA, RANCIÈRE, 2010), o autor de $O$ mestre ignorante (2013) revela os três sentidos que possui essa ignorância do mestre: no primeiro, em nível empírico, o mestre ignorante é o professor que ensina o que desconhece; no segundo sentido, a expressão "mestre ignorante" revela a figura de um professor que se faz para o aluno como um meio de conhecimento, muito embora não lhe transmita qualquer conhecimento e, por fim, no terceiro sentido, o mestre ignorante é o professor que ignora o "conhecimento de desigualdade", suposto para preparar o caminho e 'reduzir' a desigualdade. Ele se recusa a admitir a desigualdade, por acreditar somente na igualdade entre as inteligências.

Passemos a conhecer os três sentindo da ignorância em Rancière:

a) Ensinar o que se desconhece - a experiência vivenciada entre Jacotot e os estudantes flamengos revela o primeiro sentido da ignorância como a maior virtude do professor: o mestre ignorante é o professor que ensina o que desconhece. Jacotot foi obrigado a deixar seu conhecimento que, naquele momento, não lhe servia para nada e, consequentemente, suas explicações. Só assim pode se aventurar no método do acaso sem, contudo, abandonar sua relação de ensino e de aprendizagem junto aos jovens. Na experiência que perturbou seu espírito, as ligações se davam entre a vontade do autor de Telêmaco (que havia querido fazer um certo uso da língua francesa) a do tradutor (que havia querido fornecer o equivalente em holandês) e a inteligência dos aprendizes (que queriam aprender a língua francesa). E eis a evidência mais assustadora para um professor extremamente dedicado a seu ofício: nenhuma outra inteligência era necessária. Jacotot descobriu que:

[...] todas as frases e, por conseguinte, todas as inteligências que as produzem são de mesma natureza. Compreender não é mais do que traduzir, isto é, fornecer o equivalente de um texto, mas não sua razão [...] Aprender e compreender são duas maneiras de exprimir o mesmo ato de tradução (op.cit., p. 26).

Se as inteligências são de mesma natureza, não é necessário fornecer explicações. $\mathrm{Na}$ verdade, a inteligência que fizera com que os alunos aprendessem o texto de Fenélon é tão espontânea quanto a inteligência da criança pequena que ao adentrar no universo da língua materna, o faz através da inteligência da observação e da retenção, com a qual se vai repetindo e verificando, analisando e comparando suas primeiras experiências de falante da língua com aqueles veteranos eloquentes. Busca, por assim dizer, associar o que se está dominando ao que já é conhecido, fazendo e refletindo sobre o que se fez, e procedendo por adivinhação. Querendo responder, na condição de homens, a uma palavra, também humana, que lhe foi dirigida. (op. cit., p. 28-29).

A experiência de Jacotot o fez concluir que o seu ato de professor que obriga outra inteligência para o exercício em si foi independente do conhecimento que possuía. Dessa 
forma, torna-se verdadeiramente possível a um ignorante permitir que outro ignorante aprenda por sua própria inteligência algo desconhecido para ambos.

b) Ensinar sem transmitir conhecimento - o segundo sentido da ignorância do mestre está em ser a causa de conhecimento para o aluno sem lhe transmitir qualquer conhecimento. Na verdade, o que faz o mestre ignorante é abrir mão de suas explicações, que são à base da lógica pedagógica vigente em que se pretende ensinar ao aluno o que este não sabe a fim de diminuir o fosso entre sua ignorância e o conhecimento. A necessidade de explicações é para Jacotot uma evidência cega do sistema de ensino, o modo como este se organiza para tirar as pessoas da suposta ignorância; revela, na verdade, uma regressão que se estende até o infinito, pois o mestre explicador tem necessidade de tomar a palavra para explicar ao aluno, através de seu conjunto de raciocínios, o conjunto de raciocínios em que o livro se constitui, essa lógica gera sempre uma explicação da explicação, reduplicando infinitamente as razões:

\begin{abstract}
A lógica da explicação comporta, assim, o princípio de uma regressão ao infinito: a reduplicação das razões não tem jamais razão de se deter. O que detém a regressão e concede ao sistema seu fundamento é, simplesmente, que o explicador é o único juiz do ponto em que a explicação está, ela própria, explicada [...] O segredo do mestre é saber reconhecer a distância entre a matéria ensinada e o sujeito a instruir, a distância, também, entre aprender e compreender. O explicador é aquele que impõe e abole a distância, que a desdobra e que a reabsorve no seio de sua palavra. (op.cit., p.20-21-22).
\end{abstract}

É colocado em questão o fato de que um raciocínio seja preciso para explicar ao ignorante um outro raciocínio e de que, só o mestre que explica é quem pode dizer até onde a explicação está dada. O mestre passa a deter um poder acima do livro e acima do ignorante, manipulando a distância entre os dois últimos.

A hierarquia pedagógica que se estabeleceu como aceitável e inquestionável revelase como um paradoxo onde a palavra do professor ganha um status privilegiado sobre a escrita do livro e torna-se senhor quase absoluto da aprendizagem do aluno, restando a esse bem pouco a pensar. Nessa hierarquia, a explicação oral é necessária para explicar o raciocínio escrito, supondo que os raciocínios do professor são mais claros e objetivos do que os raciocínios do livro, mesmo esses estando registrados e conservados, diferentemente dos primeiros que se dissipam no mesmo instante em que são transmitidos ao aluno.

Todo o esforço do sistema explicativo é o de aperfeiçoar as explicações. Essa preocupação exacerbada com a compreensão, típica do mestre explicador (meu aluno compreendeu?) é para Rancière a mantenedora de uma inteligência que se divide em dois mundos, o das inteligências superiores e o das inferiores:

[...] compreender - a causadora de todo o mal. É ela que interrompe o movimento da razão, destrói sua confiança em si, expulsa-a de sua via própria, ao quebrar em dois o mundo da inteligência, ao instaurar a ruptura entre o animal que tateia e o pequeno cavalheiro instruído, entre o senso-comum e a ciência." (op. cit., p.25).

A dita compreensão tão cara à lógica pedagógica vigente e alvo de todos os esforços para se aperfeiçoar as explicações é a base para um progresso no embrutecimento, sendo este entendido como: a confirmação de uma incapacidade pelo próprio ato através do qual se pretende reduzi-la. (op. cit., p. 11/12). O fazer compreender que é para os pedagogos (progressistas ou tradicionais) a tarefa mais nobre do professor, torna-se para Jacotot o princípio do embrutecimento, por submeter a inteligência do aluno a do mestre. $\mathrm{O}$ 
aluno que recebe explicações aplica sua inteligência em um trabalho de morte: "compreender significa, para ele, compreender que nada compreenderá, a menos que lhe expliquem" (op. cit., p. 26).

Ao contrário da lógica pedagógica vigente, na lógica emancipadora, o mestre ignorante não exerce nenhuma relação de inteligência para inteligência. Ele se coloca como uma vontade que insere o ignorante em um círculo arbitrário de onde este pode sair sozinho, que revela ao ignorante uma capacidade que já possui, inerente a toda pessoa humana. A emancipação em Rancière é a consciência daquilo que pode uma inteligência, quando ela se considera como igual a qualquer outra e considera, da mesma forma, qualquer outra inteligência como igual a si (op. cit., p. 64). De fato, desde o seu nascimento a criança vive situações de emancipação sempre e a cada momento. A língua materna é o indicador principal dessa emancipação. Não há mestre que lhe explique a língua materna e, no entanto, é o que melhor compreende e do que mais se apropria.

A escola por outro lado, ao receber essa criança toma-a como um ser que nada sabe, e mesmo quando diz reconhecer que sabe, não abre mão de instruí-la a seu modo. $\mathrm{O}$ professor com suas explicações responsabiliza-se por apresentar a criança o mundo do saber. Desde o primeiro momento em que passa a ser instruída é retirada da criança a liberdade de aprender com os recursos que desenvolveu para utilizar a sua inteligência até esse mesmo instante. A instrução se põe primeiramente a dividir raciocínio do aluno em dois, como se houvessem duas inteligências distintas, agora que a criança passou a ser instruída. Separa-se a inteligência da vida cotidiana com os seus os procedimentos e suas aplicações que fizeram com que a criança aprendesse tudo que sabe até o momento, e a partir de então, ela deverá seguir a lógica pedagógica e seus procedimentos: progressão do mais simples ao mais complexo, de acordo com a capacidade atribuída à mente infantil. Para Rancière, a relação autônoma entre aprendizagem e verificação, a partir daí, é negada a criança. "Tudo muda quando na escola, trata-se de compreender, pois isto é o que a criança não pode fazer sem as explicações fornecidas, em certa ordem progressiva, por um mestre. Mais tarde, por tantos mestres quanto forem as matérias a compreender." ( RANCIÈRE, 2013, p. 23).

Por fim, o último sentido da ignorância:

c) Ignorar a desigualdade - o terceiro e o mais importante sentido da ignorância do mestre como uma qualidade a ser enaltecida é a sua ignorância da desigualdade. Enquanto a lógica pedagógica vigente parte da desigualdade reduzindo-a a fim de atingir uma futura igualdade, e faz uso do conhecimento da desigualdade para eliminá-la. A lógica emancipadora recusa esse conhecimento da desigualdade, porque só aceita a igualdade entre as inteligências como axioma a ser verificado. O professor deve relacionar-se com o aluno o reconhecendo enquanto homem, capaz, portanto, de compreender a inteligência de qualquer de seus semelhantes, já que não há um único homem que não tenha aprendido alguma coisa nova por si mesmo e sem recorrer a mestre que o explique. Essa é a base do "Ensino Universal" que para Jacotot, existe desde o começo do mundo ao lado de todos os métodos explicadores, sem nunca ter sido reconhecido. É ele o formador de todos os grandes homens.

Aprender sozinho e sem recorrer a mestre explicador é uma experiência repetida exaustivamente na vida de cada homem, isso supõe que aja uma igualdade básica entres todas as inteligências humanas. Rancière argumenta que é preciso verificar essa igualdade e que é possível percebê-la, pois até mesmo para que o ignorante possa cumprir as tarefas solicitadas pelo mestre deve entender o que o mestre diz. Esse fato, por si, já revela que há uma igualdade que antecede a relação de desigualdade. É a esta igualdade que Rancière chamará de igualdade de inteligências, defendendo que aquele que é, supostamente 
ignorante já aprendeu inúmeras coisas, ouvindo e repetindo, observando e comparando, por adivinhação e verificação.

\section{A igualdade entre as inteligências como princípio de uma nova filosofia da educação}

Jacques Rancière nos revela que a igualdade deve ser tomada como ponto de partida no processo de ensino aprendizagem, de outro modo ela só seria postergada até o infinito, sem nunca ser atingida, pois o próprio ato de tentá-la alcançar partindo da desigualdade faz com que ela jamais venha a se realizar. Ao partir da igualdade como único axioma a ser verificado na relação que envolve o professor com seu aluno, a lógica emancipadora toma como uma realidade a existência de uma igualdade básica entre as inteligências do mestre e do aprendiz. Destacamos que não se trata de igualdade/desigualdade entre classes, gêneros, etnias ou entre religiões, mas, entre um atributo de todo e qualquer ser humano, a inteligência que posta na relação de igualdade no âmbito da pedagogia da sala de aula, rompe a hierarquia historicamente instituída entre o mestre e o discípulo.

Para que se prove essa igualdade é necessário, entretanto, que se faça um teste prático em ato, pois, a igualdade, assim como a desigualdade, é um princípio que não pode ser autenticado por teorias ou estudos sobre o funcionamento do cérebro, mas deve ser pressuposta para ser verificada na prática, inerente que é ao espírito humano. Ou seja, a igualdade/desigualdade se constitui socialmente entre classes, grupos e indivíduos, portanto, invertê-la ou mantê-la depende de uma atitude política, no caso, do mestre.

$\mathrm{Na}$ obra que se faz objeto de estudo para este trabalho, Jaques Rancière faz importantes considerações quanto aos resultados das atividades desenvolvidas pelos alunos do louco ${ }^{7}$ Joseph Jacotot. Como o intuito do autor não se constitui em defender a tese da igualdade entre as inteligências como a verdade absoluta, ele labuta para tratá-la como uma hipótese a ser verificada, posta em prática na relação da construção dos saberes e conhecimentos entre o mestre e o discípulo. Dessa forma, a igualdade intelectual não pode ser nem uma verdade absoluta, nem um recurso retórico, mas a atitude pedagógica de criar situações onde as inteligências agem, criam, constroem e reconstroem suas compreensões sobre tal ou qual conteúdo.

Ainda, insistindo na busca da igualdade como um axioma, não obstante a defesa de sua prática na relação pedagógica, Rancière defende que a teoria da emancipação nada mais é do que uma experiência de veracidade em torno da verdade, e isso já é o bastante.

A tese da igualdade como uma hipótese que deve ser verificada está apresentada por Jacques Rancière através da legitimação da improvável e pouco aceitável tese do professor Joseph Jacotot que se desdobra nas importantes passagens de seu livro.

Rancière toma o conceito de emancipação definindo-o como tomada de consciência por parte de cada homem de sua natureza de sujeito intelectual e vai, ainda mais longe, quando declara que a emancipação seria mesmo a célebre frase do grande filósofo Descartes posta ao revés. Se Descartes diz: eu penso, logo sou, o Ensino Universal proposto por Joseph Jacotot revira sua frase e a reformula declarando: sou homem, logo, penso. Para Joseph Jacotot e, correspondentemente para Rancière, todo homem, por ser homem, guarda em seu espírito uma potência que o iguala a seus semelhantes. Esse simples fato o torna pensante (RANCIÈRE, 2013, p.60).

Essa potência humana se refere a toda manifestação do espírito humano, é ela que põe o discípulo em condição de igualdade com o mestre, pois está na ação de ambos, não importa que o professor empregue sua ação em fazer relações entre discursos científicos que o aluno ainda não conhece, e que o aluno, por sua vez, empregue a sua ação em 
relacionar as formas das letras do alfabeto; o princípio, a igualdade dessas duas inteligências encontra-se no fato de que ambas pensam por meio de relações. Dessa forma, tudo o que pode o mestre, pode também o aluno. A potência humana é que rege a prática investigativa da inteligência e nisso não há hierarquia. $\mathrm{O}$ ato de memorizar, compreender, julgar, registrar, criar... tudo, é potência humana.

A pedagogia na qual somos instruídos, inspirada no método cartesiano, divide e diferencia os atos da inteligência humana porque acredita e está pautada no axioma da desigualdade intelectual. Mesmo os discursos pedagógicos mais modernos, mantêm essa crença afirmando que há etapas no desenvolvimento da inteligência e que a inteligência de uma criança é diferente da inteligência de um ser adulto e, assim, vai-se edificando os tronos da hierarquia criada e mantida das inteligências (op.cit., p. 46).

Contrariando a essa pedagogia que faz questão de manter a distância que separa o aluno do mestre e que, por sua vez, mantém o primeiro sempre carente das explicações do segundo, por meio dos princípios que a regem, tal como; a seleção, a progressão e a incompletude: o primeiro seleciona o grau de dificuldade de conteúdos a serem abordados paulatinamente; o segundo define a hierarquia do fácil para o difícil e o terceiro, é o abismo da ignorância do aluno em relação ao conhecimento (op. cit., p. 41).

Em nossa análise constatamos que o método da emancipação se inspira em princípios próprios. Ao invés de seleção de conteúdos, o todo: o livro ou qualquer outra coisa. Ao invés de progressão, a marcha própria de cada aluno. Ao invés de incompletude, o círculo da potência que é o ato do mestre em encerrar a inteligência do aluno em um círculo arbitrário do qual esta não poderá sair se não se tornar útil a si mesma (op. cit., p. 34). Mas o que esses princípios significam? Em que se fundamentam? Vamos à exposição do louco.

O primeiro princípio que rege o Ensino Universal é exatamente "aprender qualquer coisa" (op. cit., p. 41) e, a isso, relacionar todo o resto. Princípio, este, que a pedagogia vigente renega e ignora, pois a sua razão primeira é selecionar e hierarquizar, de antemão, os conteúdos que os alunos irão aprender desde o primeiro momento em que adentram à escola, tornando-os incapazes de se reconhecerem sujeito de sua aprendizagem:

Aprendem-se algumas regras e alguns elementos, que são aplicados a alguns trechos escolhidos de leitura, alguns exercícios correspondendo aos rudimentos adquiridos. Em seguida, passa-se a um nível superior: outros rudimentos, outro livro, outros exercícios, outro professor... A cada etapa, cava-se o abismo da ignorância que o professor tapa, antes de cavar um outro. Fragmentos se acrescentam, peças isoladas de um saber do explicador que levam o aluno a reboque de um mestre que ele jamais atingirá. O livro nunca está inteiro, a lição jamais acabada. O mestre sempre guarda na manga um saber, isto é, uma ignorância do aluno ( $o p$. cit., p. 41).

É importante ressaltar que nesta condição, o aluno é mutilado de tal forma sútil que não lhe causa sofrimento, mas uma dependência legitimada e acatada, ele jamais se sentirá capaz de aprender qualquer coisa a menos que isso lhe seja ensinado por um mestre explicador.

Também nessa condição o aluno apenas aprende o conteúdo para depois esquecerse dele, para a pedagogia vigente aquilo que foi em algum momento aprendido, foi também superado, de modo que já não é necessário lembrar-se, pois a inteligência que o absorveu uma vez tornou-se superior. Rancière declara ser exatamente esta a natureza do mestre explicador: inferiorizar o aluno amarrando-o ao país do embrutecimento a partir da 
consciência de ser superior aos que ficaram para trás nas lições que a sua inteligência já conheceu (op.cit., p. 42).

O Ensino Universal proposto por Joseph Jacotot, e reatualizado por Jacques Rancière, defende que para aprender, não é necessário que outrem, que não o próprio sujeito da aprendizagem, o aluno, selecione conteúdos e formas de aprendizagem. Afinal de contas, aprendemos tantas coisas na vida sem que nos seja preciso explicações sobre o que e como aprender. Se assim pensamos, somos então obrigados a concordar que podemos aprender aquilo que está escrito no livro da mesma forma como compreendemos todas as coisas. E como um ignorante aprende todas as coisas? O Ensino Universal responde: comparando dois fatos (op. cit., p. 43). Essa é a ação natural da inteligência humana, aprendemos através das relações que a inteligência estabelece entre o que já nos é conhecido e aquilo que pretendemos conhecer ou desvendar.

O Ensino Universal requer sempre a presença da materialidade do livro (ou de qualquer outra coisa) como condição fundamental de seu 'método'. Assim, na lógica da emancipação intelectual o objeto do conhecimento (um livro, um quadro, um experimento ou mesmo um bordado) exerce um importante papel, pois em qualquer um deles o conhecimento pode ser explorado livremente. O livro ou a coisa é que formará com o aluno e o mestre o círculo da potência:

O livro é uma fuga bloqueada: não se sabe que caminho traçará o aluno, mas sabe-se de onde ele não sairá - do exercício de sua liberdade. Sabese, ainda, que o mestre não terá o direito de se manter longe, mas à sua porta. $\mathrm{O}$ aluno deve ver tudo por ele mesmo, comparar incessantemente $\mathrm{e}$ sempre responder à tríplice questão: o que vês? o que pensas disso? o que fazes com isso? E, assim, até o infinito (op.cit., p. 44).

O círculo da potência abole a grande trapaça da pedagogia vigente que é incapacidade do aluno:

[...] O livro, quanto a ele, está pronto e acabado. É um todo que o aluno tem em mãos, que ele pode percorrer inteiramente com um olhar. Não há nada que o mestre lhe subtraia, e nada que ele possa subtrair ao olhar do mestre. O círculo abole a trapaça. E, antes de mais nada, essa grande trapaça, que é a incapacidade: eu não posso, eu não compreendo...Não há nada a compreender. Tudo está no livro. Basta relatar a forma de cada signo, as aventuras de cada frase, a lição de cada livro. É preciso começar a falar (op.cit., p. 44).

O caminho proposto pelo Ensino Universal não é em nada uma novidade estarrecedora, é na verdade a coisa mais antiga do mundo, um caminho conhecido por todos os homens. A única coisa que o Ensino Universal sugere é que cada homem siga-o sem se afastar (op.cit., p. 44). Para tanto, nada mais é exigido que não vontade e atenção absoluta ao que se faz. Deste modo, o livro, funcionará como um todo que o aluno terá em mãos, um todo que poderá percorrer inteiramente com um olhar. Do qual o mestre nada poderá ocultar ao aluno, nem o aluno ao mestre, pois o livro é um todo pronto e acabado, aberto e entregue a todos os que tenham vontade de lhe conhecer e desvendar. Não é o mestre quem determinará o que o aluno deverá aprender, é o livro, enquanto objeto de conhecimento, e a vontade própria do aluno em desvendá-lo.

O segundo princípio, que se relaciona a marcha própria de cada aluno é, na verdade, o reconhecimento, de que, cada homem é capaz de instruir-se a si mesmo. Rancière defende o Ensino Universal como o método da vontade, afirmando que todo ignorante pode aprender sozinho e sem a presença de um mestre explicador (op. cit.; p. 
30). Deste modo, é a vontade do indivíduo ou a eventual situação em que esteja inserido que comanda o progresso de seu aprendizado.

Para se aventurar em algo que até então lhe era desconhecido o ignorante deve unicamente se dispor a aprender uma nova língua, assim como aprendeu a língua materna. Jacques Rancière exemplifica o sentido de "aprender a falar uma nova língua" no Ensino Universal, descrevendo a aventura intelectual das camponesas de Grenoble que fabricavam luvas e as vendiam por trinta centavos, a partir da experiência de emancipação essas mulheres passaram aperfeiçoar seu ofício, estudando e compreendendo uma luva bem confeccionada. Aprenderam a falar uma nova língua através de agulhas e tesouras, e passaram a ganhar sete francos por suas luvas. É por isso que no Ensino universal a questão sempre estará em compreender e falar uma nova língua (op.cit.; p. 62).

E como um ignorante pode alcançar a emancipação? Refletindo e reconhecendo suas capacidades intelectuais, nas palavras de Jacques Rancière:

\begin{abstract}
A consciência da emancipação é, antes de tudo, o inventário das competências intelectuais do ignorante. Ele conhece sua língua. Ele sabe, igualmente, usá-la para protestar contra seu estado ou para interrogar os que sabem, ou acreditam saber, mais do que ele. Ele conhece seu ofício, seus instrumentos e uso; ele seria capaz, se necessário, de aperfeiçoá-los. Ele deve começar a refletir sobre essas capacidades e sobre a maneira como as adquiriu (op. cit.; p. 61).
\end{abstract}

Assim, o ignorante aprenderá a falar tantas novas línguas quanto queira, a partir da consciência da universal verificação do semelhante, de que todos os emancipados são capazes. Esse é o sentido essencial do Ensino Universal (op. cit.; p. 67).

Ao mestre emancipador caberá apenas verificar o quanto de atenção o aprendiz usou para realizar o seu trabalho intelectual. Sendo assim, o mestre realiza o ato do examinador ignorante, que é levar o examinado aos objetos materiais, e fazê-lo verificar esses objetos usando seus próprios sentidos. O examinado ignorante, que é o aprendiz, estará por sua vez, sempre sujeito a uma verificação por parte do mestre também a partir dos objetos materiais. Isso significa que as inteligências do mestre e do aprendiz são independentes entre si. O aluno estará, assim, sozinho em seu próprio caminho de emancipação intelectual e a competência intelectual do mestre, no Ensino Universal, passa a ser evidenciada pela verificação que faz, não tanto da ciência a qual o aluno terá de compreender, mas da atenção que ele dá ao que diz e faz para compreender essa ciência.

\footnotetext{
[...] É assim que o mestre ignorante pode instruir tanto aquele que sabe quanto o ignorante: verificando se ele está pesquisando continuamente. Quem busca, sempre encontra. Não encontra necessariamente aquilo que buscava, menos ainda aquilo que é preciso encontrar. Mas encontra alguma coisa nova, a relacionar à coisa que já conhece. O essencial é essa contínua vigilância, essa atenção que jamais se relaxa sem que venha a se instalar a desrazão - em que excelem tanto aquele que sabe quanto o ignorante. $O$ mestre é aquele que mantém o que busca em seu caminho, onde está sozinho a procurar e o faz incessantemente (op.cit.; p. 56/57).
}

A condição fundamental para ser um mestre ignorante e emancipador, é que se tenha emancipado a si próprio e que se reconheça como sujeito intelectual que participa da potência comum dos seres intelectuais. Uma vez emancipado, qualquer homem pode tornase um mestre emancipador.

Rancière afirma que esse conhecimento de si próprio, essencial à emancipação, refere-se à reflexão constante sobre o que se é e o que se faz na ordem social. Essa condição é legítima a cada homem, desde o mais simples dos seres humanos. Contudo, a 
pedagogia vigente, ainda que de forma muito sútil, está fundamentada no mandamento platônico que declara ao homem do povo:

Não faças nada além de teu próprio negócio, que não é de pensar no que quer que seja, mas simplesmente fazer essa coisa que esgota a definição do teu ser: se tu és sapateiro, calçados e crianças que serão sapateiros. Não é a ti que o oráculo délfico recomenda conhecer-se. E, mesmo se a divindade, brincalhona, se divertisse em semear na alma de teu filho um pouco do ouro do pensamento, é à raça de ouro, aos guardiães da pólis que incumbiria a tarefa de educá-lo, para torná-lo um deles (op. cit.; p. 57/58).

Ainda que com o progresso, esse mandamento tenha sido abrandado, o seu fundamento permanece nas práticas, métodos e teorias que regem o ensino e aprendizagem, especialmente, no que refere a hierarquia entre as inteligências do mestre e do aprendiz. Isso porque a perpetuação do velho mandamento platônico garante a integridade e a manutenção das posições hierárquicas na escala social e intelectual. Para garantir que a engrenagem social funcione perfeitamente, com cada um na sua posição, a pedagogia vigente esforça-se para garantir que um sapateiro mantenha-se distante de sua percepção enquanto um homem intelectual e perceba-se apenas como um sapateiro; mesmo tendo consciência de que tal homem jamais será simplesmente sapateiro, sendo também à sua maneira, gramático, físico, mestre etc. Isso por que: “[...] a mesma natureza que abre a carreira das ciências a todos os espíritos quer uma ordem social em que as classes estejam separadas e os indivíduos conformados ao estado social que lhes é destinado" (op.cit.; p.59).

A estratégia para atingir tal objetivo é a diferenciação da instrução que fica por conta do mestre explicador e da educação que fica a cargo da família:

Um afugenta, pelas luzes da instrução, as idéias falsas que a criança deve a seu meio familiar; o outro afugenta, pela educação, as aspirações extravagantes que o escolar poderia tirar de sua jovem ciência e o traz de volta à condição dos seus. O pai de família, incapaz de tirar de sua prática rotineira as condições para a instrução intelectual de seu filho, mostra-se, em troca, todo-poderoso para lhe ensinar, pela palavra e pelo exemplo, a virtude que há em se manterem sua condição. A família é, ao mesmo tempo, fonte da incapacidade intelectual e princípio de objetividade ética. Esse duplo caráter se traduz por uma dupla limitação da consciência de si do artesão: a consciência de que aquilo que faz depende de uma ciência que não é a sua, a consciência de que aquilo que é o conduz a não fazer nada, além de seu próprio negócio. (op. cit.; p. 59/60)

O mandamento emancipador se impõe para desmistificar essa relação em que o mestre e o pai de família desempenham seus papéis sociais de forma tão natural e levantar a suspeita de que essa relação poderia ser radicalmente diferente, se a hipótese da igualdade de inteligências pudesse ser ao menos verificada. Esse mandamento defende a tomada de consciência, por parte de cada homem, de sua natureza de sujeito intelectual; e acredita poder comandar um homem que é, por sua vez, capaz de comandar a si próprio. Assim:

Para transformar o 'conhece-te a ti mesmo' em princípio da emancipação de todo ser humano, é preciso fazer operar, contra o interdito platônico, uma das etimologias da fantasia do Crátilo: o homem, o anthropos, é o ser que examina o que vê, que se conhece nessa reflexão sobre seu ato. Toda a prática do Ensino Universal se resume na questão: o que pensas disso? Todo seu poder está na consciência da emancipação que ela atualiza no mestre, e suscita no aluno. O pai 
poderá emancipar seu filho, se começar por se conhecer a si próprio, isto é, por examinar os atos intelectuais de que é o sujeito, por observar a maneira como utiliza, nesses atos, seu poder de ser pensante (op.cit.; p. 60/61).

Um pai de família pode instruir seu filho a não parecerá estranho se se acredita que todos são homens, são iguais e intelectualmente capazes; e isso é tudo o que se pede no Ensino Universal, que se acredite na potência humana comum a todos e inerente a cada um.

A hipótese da igualdade entre as inteligências nos apresenta ainda um terceiro princípio que acastela ser possível encerrar aquele que é supostamente ignorante em uma situação na qual a igualdade de princípio dos seres falantes possa ser maximizada, em que ela possa ser tomada como ponto de partida, produzindo seu efeito através de sua constante verificação. Para isso, não são exigidas performances pedagógicas especiais como acontece na pedagogia vigente. Qualquer um que seja emancipado é essencialmente capaz de ser emancipador, sua função é despertar naquele que se pretende emancipar a consciência daquilo que pode uma inteligência, quando ela se considera como igual a qualquer outra e considera qualquer outra como igual a sua (op.cit.; p. 64).

Por esse motivo um pai de família ignorante pode forçar a vontade do filho o encerrando no círculo da potência, e verificar assim, que os dois têm igual inteligência. Nesse círculo o filho, ao pesquisar, buscará no livro a inteligência daquele que o escreveu e também verificará que ambos tem igual inteligência. Jacques Rancière revela ser este o cerne do método emancipador, que aflora o princípio de uma filosofia nova, a qual o louco Joseph Jacotot, juntando duas palavras gregas, batizou de Panecástica, porque ela busca o todo da inteligência humana em cada manifestação intelectual. Segundo Leal (2008, p.8) a filosofia Panecástica é definida pela junção das palavras gregas pan(tudo) e hekastos(cada), que significa: tudo em cada ou tudo está em tudo.

As diversas pedagogias acreditam ser a falta de instrução que embrutece o povo, o Ensino Universal acredita ser a crença na inferioridade de sua inteligência o que embrutece, e embrutece não somente aos "inferiores", mas igualmente aos que se acreditam "superiores" (op. cit.; p.65).

A nova filosofia que é a da emancipação, é a consciência da igualdade, da reciprocidade entre as inteligências humanas e, somente ela permitirá o surgimento de uma nova consciência e de uma superação de si, em que cada homem refletirá sobre a sua ação intelectual até percebê-la enquanto exercício integral da razão comum da humanidade.

\section{3 - A igualdade entre as inteligências e a sociedade razoável}

A terceira lição deixada pelo método de Jacotot é a de que a emancipação supõe um funcionamento igual, universal das inteligências (VERMEREN, CORNU e BENVENUTO, 2003). Como já foi dito em outro momento, a igualdade das inteligências é apenas uma opinião e o autor Jacques Rancière deixa claro que uma opinião não deve ser tomada como verdade, e que, tão pouco, deve ser tomada como algo superficial e inferior como a crê o conhecimento dito científico. Para os defensores do Ensino Universal as opiniões são as descobertas que fazemos enquanto estamos no caminho em busca da verdade, e isso é muito importante. Sendo assim, nenhuma pretensão há de defender a opinião da igualdade entre as inteligências como sendo verdadeira. $\mathrm{O}$ que se pretende é verificar o que se pode fazer a partir da suposição de que todas as inteligências são iguais (Rancière, 2013, p.72). Para isso, é necessário que compreendamos que assim como não se pode tomar a igualdade como um dogma absoluto, torna-se igualmente impossível dar a desigualdade entre as inteligências esse lugar. Ambas são opiniões. 
Rancière defende que a faculdade da inteligência humana seja imaterial, por isso mesmo pode-se defender a hipótese de que há igualdade entre as inteligências; pois, sendo imaterial, não há critério único e seguro para dizer que um sujeito seja mais ou menos inteligente que outro, em outras palavras, pode-se dizer que os atributos de uma pessoa inteligente variam de um grupo social para outro, dependendo das exigências sócio históricas que o tempo e o espaço físico e cultural fazem à seus membros.

Aqueles que defendem a desigualdade entre as inteligências aceitam que aja uma igualdade de espírito mínima entre os homens, mas não igualdade intelectual. Acreditam que assim, a desigualdade das inteligências está para todo sempre justificada. Rancière esclarece o pensamento dos defensores da desigualdade:

[...] há em todo homem, dizem eles, uma alma imaterial. Ela permite ao mais humilde conhecer as grandes verdades do bem e do mal, da consciência e do dever, de Deus e do julgamento. Quanto a isso, somos todos iguais e até concedemos que os mais humildes frequentemente nos superariam. Que isso lhes baste, pois, e não aspirem, ademais, a essas capacidades intelectuais, que são privilégio - muitas vezes, pesadamente adquirido - daqueles que têm por tarefa cuidar dos interesses gerais da sociedade (op. cit.; p. 75).

Ao passo que concebem, tão gentilmente, aos inferiores uma alma imaterial, os defensores da desigualdade entre as inteligências nega aos homens do povo a equidade intelectual que lhe é devida.

Em oposição àqueles que defendem a inteligência como algo particular a cada indivíduo e que se esforçam para justificar a hierarquia intelectual, Rancière, através da experiência de Jacotot, defende o princípio de que os indivíduos são igualmente inteligentes, fazendo constatações a partir da observação das manifestações das inteligências. Partindo do pressuposto de que o homem faz coisas que os outros animais não são capazes de fazer, o que lhe confere, segundo o autor, um espírito, uma inteligência. Só o homem, dentre todos os animais, pode dispor de uma linguagem articulada, e criar por meio dela, palavras, figuras, frases e comparações, para comunicar-se com seus semelhantes. (op. cit.; p. 77).

Rancière também observa que quando dois homens, vivendo nas mesmas condições, são comparados nos primeiros momentos da vida, eles têm absolutamente a mesma inteligência, fazendo as mesmas coisas, com o mesmo objetivo e intenção. Suas inteligências são iguais, entendendo a expressão "inteligência igual" como um resumo de todos os fatos que se constata ao observar duas crianças nos primeiros anos de vida. (op. cit.; p. 77/78).

A terceira observação é a de que com o passar dos anos e desenvolvimento desses dois homens, constatar-se-á que suas inteligências já não fazem as mesmas coisas, não mais obtêm resultados semelhantes. A partir desse ponto o Ensino Universal estabelece a suposição de que as faculdades desses homens não foram igualmente exercidas e declara: "Nada me concede certeza quanto a isso, mas nada me prova o contrário. Que a um faltou exercício intelectual". O Ensino Universal nega-se em defender que um homem é menos bem sucedido intelectualmente porque é menos inteligente. Concebe, ao contrário, que um homem possa realizar um mau trabalho intelectual por dedicar a seu trabalho menor atenção.

A atenção que se emprega ao realizar um trabalho intelectual fará toda a diferença na manifestação das inteligências desses dois homens. É somente ai que elas se diferenciam, mas ambos têm igual inteligência, pois: 
A atenção não é nem uma bossa do cérebro, nem uma qualidade oculta. $E$ um fato imaterial em seu princípio e material em seus efeitos: temos mil e um meios de verificar sua presença, sua ausência ou sua maior ou menor intensidade. É para isso que tendem todos os exercícios do Método Universal (op.cit.; p. 78).

Ao defender que a atenção é um ato imaterial em seu princípio e material em seus efeitos, o autor esclarece que, embora não se possa perceber o quanto de atenção o aprendiz emprega enquanto trabalha, é possível percebê-la sempre que sua inteligência se manifesta a respeito. E assim, atenção empregada ao trabalho intelectual determina a qualidade da manifestação de cada inteligência.

Dentro da lógica emancipatória proposta em Rancière o desenvolvimento da inteligência deve ser entendido como uma associação entre a vontade e o poder racional. Nas crianças pequenas a necessidade de se inserir no mundo dos falantes as leva a utilizar sua inteligência exaustivamente, por esse motivo demonstram uma inteligência tão semelhante em sua exploração do mundo e em seu aprendizado da linguagem. Na explicação de Rancière:

$\mathrm{O}$ instinto e a necessidade os conduzem de forma idêntica. Todas têm mais ou menos as mesmas necessidades a serem satisfeitas e todos querem igualmente entrar na sociedade dos humanos, na sociedade dos seres falantes. E, para isso, é preciso que a inteligência trabalhe sem repouso. "Esta criança está rodeada de objetos que lhe falam, todos ao mesmo tempo, em línguas diferentes; é preciso que ela os estude separadamente, e em seu conjunto; eles não têm entre si qualquer relação e, frequentemente, se contradizem. Ela nada pode adivinhar sobre esses idiomas que a natureza fala, ao mesmo tempo a seu olho, a seu tato, a todos os seus sentidos. É preciso que esteja sempre repetindo, para poder se lembrar de tantos signos absolutamente arbitrários [...] Quanta atenção é necessária, para tudo isso!" (op. cit.; p. 78/79).

É a vontade de aprender e de procurar incessantemente, por iniciativa própria, que confere significado às coisas. Assim, cada homem desenvolve a inteligência que as circunstancias e/ou a sua necessidade lhes exigem. Quando a necessidade acaba é necessário que surja uma vontade ainda mais forte que a necessidade que declare a inteligência que dorme: "continua; vê o que fizeste e o que podes fazer se aplicares a mesma inteligência que já empregaste, investindo em toda coisa a mesma atenção, não te deixando distrair em teu caminho." (op. cit.; p. 79). Essa vontade pode pertencer ao próprio indivíduo, uma vez que seja emancipado, ou pode ser a de um mestre ignorante. Em resumo, Jacques Rancière defende que "o homem é uma vontade servida por uma inteligência", definindo o termo inteligência como a busca; e atenção e vontade como a potência de agir segundo movimento próprio (op. cit.; p. 83).

Com este pensamento, Jacques Rancière se opõe a máxima cartesiana na qual o homem é um ser dissociado do corpo e a substitui por um novo adágio no qual o homem é um ser racional que se experimenta através da ação que exerce sobre seu próprio corpo. $\mathrm{O}$ homem, segundo a lógica do Ensino Universal, é a própria vontade, é a potência:

Essa vontade não é nem meu braço, nem minha mão, nem meu cérebro, nem o tateio. Essa vontade sou eu, é minha alma, é minha potência, é minha faculdade. Sinto essa vontade, ela está presente em mim, ela sou eu; quanto à maneira como sou obedecido, não a sinto, não a conheço 
senão por seus atos. [...] Considero a ideificação como um tatear. Tenho sensações quando me apraz: ordeno a meus sentidos fornecê-las. Tenho idéias quando quero: ordeno a minha inteligência buscá-las, tatear. A mão e a inteligência são escravos, cada uma com suas atribuições. O homem é uma vontade servida por uma inteligência (op. cit.; p. 83/84).

A vontade ganha significação na pedagogia proposta na obra de Rancière, ela é o motor da inteligência, tanta é sua importância para este método que o autor defende que sem ela não há ato intelectual:

Agir sem vontade ou sem reflexão não produz um ato intelectual. O efeito que daí resulta não pode ser classificado entre as produções da inteligência, nem comparado com elas. Na inação, não se pode ver nem mais, nem menos ação; não há nada. (op.cit.; p. 84).

Abro aqui um parêntese para levantar algumas reflexões sobre as escolas que estão postas em nossa sociedade e sobre a sua pedagogia. Quantas são as atividades realizadas sem vontade por alunos e professores? Se onde não há vontade, não há potência e não há também ato intelectual, para que servem essas escolas afinal? A quem servem se não ao desenvolvimento igualitário de todas as inteligências?

Jacques Rancière defende que $o$ ato próprio e natural da inteligência é a comparação que aliada ao exercício da repetição garantem o êxito intelectual do indivíduo. Vendo ao acaso a inteligência precisa criar condições para ver de novo o que já foi visto, ou seja, precisa repetir intencionalmente. Depois ainda precisa criar palavras, frases e figuras ou qualquer outra forma de linguagem para dizer aos seus semelhantes aquilo que viu. Assim, todo homem pode aplicar sua inteligência a comparação, a repetição e a partilha de sua palavra que se carrega ou se esvazia de acordo com sua vontade, esse é o uso natural da inteligência humana e o que também a torna igual em cada homem. Para Rancière é esse o segredo dos grandes gênios e também do Ensino Universal. O homem terá somente que saber dobrar o corpo aos hábitos necessários, para ordenar à inteligência novas ideias e novas formas de exprimi-las.

Através de seus fundamentos, o Ensino Universal proclama que um indivíduo pode tudo o que quiser (op. cit.; p. 85), entretanto, esse querer não dá a nenhum homem poder sobre seus semelhantes através da exploração dos poderes da sua vontade. Esse querer é isso sim, a exploração dos poderes de todos os indivíduos quando se sabem iguais entre si e capazes de agir. Em suma, esse querer pertence a um ser racional que conhece sua potência, do mesmo modo que reconhece a de seus semelhantes e que jamais se mente esse respeito (op. cit.; p. 86).

Para o Ensino Universal, todo homem que diz não saber ou não ser capaz se ilude. E o princípio da veracidade - que é a relação privilegiada de cada um com a verdade e o cerne da experiência de emancipação aqui detalhada - está no poder de conhecer, que pertence a todos os homens sem distinção.

Em nossa compreensão, a experiência de emancipação defende a verdade de cada homem construída na sua relação individual com o conhecimento enquanto a pedagogia mantida pela escola explicadora nos faz acreditar que há somente um conhecimento e uma verdade a que ela defende e proclama:

Assim, cada um de nós descreve, em torno da verdade, sua parábola. Não há duas órbitas semelhantes. E é por isso que os explicadores põem nossa revolução em perigo. 'Essas órbitas das concepções humanitárias se cruzam raramente, e não têm senão alguns pontos em comum. As linhas 
mistas que descrevem jamais coincidem sem uma perturbação que suspende a liberdade e, por conseguinte, o uso da inteligência que dela deriva. $\mathrm{O}$ aluno sente que ele jamais teria seguido o caminho em que acaba de ser precipitado; e se esquece de que há mil sendas abertas para a vontade nos espaços intelectuais' 'Essa coincidência de órbitas é o que denominamos embrutecimento (op.cit.; p. 89).

O Ensino Universal não conhece a coincidência de órbitas em torno da verdade, e defende que cada homem construa sua verdade sobre tal ou qual conhecimento. Se um homem não está em sua órbita própria sua relação com a verdade é anulada.

Ninguém pode esperar que os defensores da desigualdade, reconheçam a órbita própria de cada homem, eles querem uma órbita comum a todos, assim comunicam um pensamento superior ao qual todos devem seguir como verdade. No Ensino Universal nenhum pensamento é dito em verdade, mas se exprime em veracidade. De acordo com essa ideia, o pensamento, uma vez expresso, se divide, se relata e se traduz por um outro indivíduo que fará para si, um outro relato e uma outra tradução com a vontade de se comunicar e de adivinhar o pensamento do outro. Nesse processo é a vontade que advinha a vontade. O pensamento que existe a princípio de forma imaterial torna-se material para ser comunicado. Por outro lado, volta a se tornar imaterial na mente daquele que o absorve e a reverter-se em material quando este o compartilha a um terceiro:

Os pensamentos voam de um espírito a outro nas asas da palavra. Cada vocábulo é enviado com a intenção de carregar um só pensamento, mas, apesar disso, essa palavra, esse vocábulo, essa larva se fecunda pela vontade do ouvinte; e o representante de uma mônada torna-se o centro de uma esfera de ideias que irradiam em todos os sentidos, de forma que o falante, para além do que quis dizer, disse realmente uma infinidade de coisas; ele formou o corpo de uma ideia com tinta, e essa matéria destinada a envolver misteriosamente um só ser imaterial contém realmente um mundo desses seres, desses pensamentos. (op. cit.; p. 89).

Não existem mistérios para a aplicação do método da emancipação intelectual, os recursos utilizados são os mesmos que estão presentes em qualquer forma de comunicação entre os homens, um livro, um quadro, uma escultura, etc. enfim, tudo o que permita que a potência humana seja exercida no confronto de tradução e contratradução entre dois seres falantes. Improvisar e relatar tornam-se também as duas operações mestras da inteligência nesse processo. A improvisação além de ser inerente a nossa virtude poética é também o exercício pelo qual conhecemos e confirmamos a nossa natureza de seres razoáveis, capazes de fazer palavras, figuras e comparações a fim de se comunicar com nossos semelhantes.

O exercício da palavra é a base para que se desenvolva a aprendizagem na lógica do Ensino Universal. Assim, a lógica emancipadora compreende que todas as obras humanas são discursos e que sua virtude está mais no fazer do que no saber. Portanto, o falar é a melhor prova da nossa capacidade de fazer seja o que for, uma vez que ao falar o homem não transmite o seu saber, "o poetiza, o traduz e convida seus ouvintes a fazer o mesmo" (op. cit.; p. 96). Deste modo, é necessário que o ignorante simplesmente fale sobre aquilo que está a aprender.

Falar sobre aquilo que se quer aprender é o primeiro passo do aluno no método proposto pelo louco professor francês, Joseph Jacotot. E esse será um exercício repetido a exaustão, a cada vez que é perguntado sobre um livro, uma pintura ou as notas de que compõe uma música, o aluno tornar-se-á mais vigilante e mais consciencioso de sua 
capacidade intelectual. O que se pretende por meio deste exercício é demonstrar que toda obra humana é uma língua que pode ser compreendida e também falada por qualquer um dos homens (op. cit.; p. 98).

Não se trata de formar ao aluno como um grande escritor, pintor ou músico, trata-se de emancipá-lo a ponto de se conscientizar de que também o pode, se assim deseja e de despertar-lhe para o sentimento de poder comum de todo ser razoável (op. cit.; p. 99), compreender que ele, assim como cada homem pode tudo o que quiser, pois tem uma alma e sentimentos a partilhar com seus semelhantes.

Uma vez consciente de que pode tudo o que quiser, o homem deve aprender a língua própria a cada coisa que deseja fazer. Para fazer música é preciso aprender a língua da música. E nesse ponto, Jacques Rancière nos revela a lição que deveremos aprender dos poetas, tomando a exemplo, o grande poeta Rancine ${ }^{8}$, esses conhecem o segredo do Ensino Universal: "aprender, repetir, imitar, traduzir, decompor, recompor" (op. cit.; p. 100). Assim, todo o poder do poeta se encontra na tradução e na contratradução. Em outras palavras, o poema escrito pelo poeta é sempre a tradução de um outro poema, que é improvisado pelas emoções e expressões humanas, todo trabalho do poeta consiste em tentar expressar em palavras o instante preciso dessas emoções e expressões humanas. Contudo, o que verdadeiramente fará sentido ao poema escrito é a contratradução que é feita pelo ouvinte, esta produzirá a emoção do poema. Por esse motivo é que o poeta tanto se esforça em arranjar e rearranjar palavras, ainda que se saiba que as palavras não podem transmitir a exatidão das emoções e que cada homem, ao ler aquele poema, terá de recorrer a sua potência humana, ou a seu gênio, para adivinhar o que o poeta quis dizer (op.cit.; p. 103). O poeta reconhece que fala a semelhantes e não a espíritos inferiores, por isso realiza sua obra sobre as bases do sentido da igualdade entre as inteligências. Assim, Rancière nos revela, aos professores, que os artistas passam uma lição oposta a sua:

A lição emancipadora do artista, oposta termo a termo à lição embrutecedora do professor, é a de que cada um de nós é artista, na medida em que adota dois procedimentos: não se contentar em ser homem de um ofício, mas pretender fazer de todo trabalho um meio de expressão; não se contentar em sentir, mas buscar partilhá-lo. O artista tem necessidade de igualdade, tanto quanto o explicador tem necessidade de desigualdade (op. cit.; p. 104).

Os professores explicadores em suas escolas com a preocupação de transmitir o conhecimento que possuem às mentes dos alunos, acreditando piamente que de outro modo eles jamais aprenderão, acabam por produzem e reproduzem uma sociedade dividida e desigual. Os poetas, por outro lado, oferecem a possibilidade de criação de um modelo da sociedade razoável, onde tudo passa pela vontade de expressar e de partilhar com o semelhante àquilo que os torna iguais.

$\mathrm{E}$, assim, Rancière descreve como a comunidade dos iguais seria constituída, uma sociedade de emancipados ou de artistas onde todos os homens saberiam que ninguém nasce com mais inteligência e que a diferença entre um e outro artista na aplicação de sua arte se refere, tão somente, a aplicação particular do poder que é comum a todos os homens. Nessa sociedade não haveria a mentira que declara que tais homens nascem para ocupar tais posições. E a dignidade humana estaria na consciência por parte de cada indivíduo de que nasceu para ser feliz em si mesmo e por si mesmo.

$\mathrm{Na}$ sociedade dos iguais, os homens estariam unidos pelo mais sólido dos laços possíveis: a inteligência comum a todos, que faz com que cada um partilhe com seu semelhante tudo que é próprio dos homens. Nessa sociedade não haveria leis ou autoridades, todos obedeceriam somente a razão. Não a razão de uns sobre os outros, mas a 
razão própria de cada um, que se faz livre dos discursos pela necessidade de ter razão e que reconhece a igualdade entre os homens. Sobre esta igualdade nos fala o autor:

[...] não uma igualdade decretada por lei ou pela força, nem uma igualdade recebida passivamente, mas uma igualdade em ato, verificada a cada passo por esses caminhantes, que, em sua constante atenção a si próprios e em sua infinita revolução em torno da verdade, encontram as frases próprias para se fazerem compreender pelos outros (op. cit.; p. 106).

Não pensemos que Rancière apenas sonhe com esta sociedade dos iguais, ele de fato acredita na hipótese levantada por Joseph Jacotot de que os homens são dotados de igual inteligência. E por acreditar, tenta verificar seu pressuposto sem, contudo, estabelecer a verdade definitiva, pois é justamente a dúvida que a opinião de Jacotot carrega que sustenta a crença numa sociedade de homens iguais.

A verificação da hipótese da igualdade entre as inteligências implica que se realize entre nós o exercício da potência humana e, para Jacques Rancière, esse exercício além de ser o mais doce dos prazeres humanos é também a nossa mais imperiosa necessidade (op. cit.; p. 106). Compreender a igualdade entre as inteligências no processo de ensinoaprendizagem implica a possibilidade de se estabelecer entre os homens uma relação de comunicação equânime, falar a semelhantes, tomando a igualdade como ponto de partida de uma nova teoria e prática docentes.

\section{Conclusão}

Apesar da crença na existência de uma sociedade formada por homens iguais, o autor Jacques Rancière não é ingênuo, sabe que ela não existe, pelo menos enquanto não a fizermos existir. A que existe, segundo sua visão, é a do desprezo, a que vê no método da emancipação um corruptor das mentes que precisa ser suprimido antes que se espalhe como um câncer. Pois, é impensável que uma sociedade dita civilizada dê a qualquer um a oportunidade de abrir uma escola, ainda mais quando esse qualquer um não apresenta a certificação, que seria a prova de sua capacidade intelectual e que prevalece socialmente. Inaudito ainda, confiar uma turma de jovens a um mestre ignorante que, não bastasse sua ignorância, gaba-se dela. A sociedade existente jamais admitirá esse fato, pois significaria a ruína de suas instituições e mestres. Assim, com opiniões tão sólidas a ponto de creemnas verdadeiras, embora não passem de opiniões, a sociedade existente pensa fazer grandes progressos quando na verdade permanece estática no que se refere a intelectualidade humana.

Apesar desse lamentoso quadro social, todo homem que escolhe acreditar no poder da opinião levanta em 1818 pelo louco e desacreditado professor Joseph Jacotot, pode verificar a veracidade dessa opinião e resistir assim, às relações embrutecedoras que perpetra a sociedade do desprezo. Tal homem, uma vez emancipado pela consciência de sua potencia humana, pode tornar-se um mestre ignorante e dedicar-se a espalhar essa boa nova a tantos homens quanto puder, é isso que se pede no Ensino Universal, que se acredite na igualdade universal das inteligências e que se ponha a espalhar essa ideia a todos os homens.

Em nossa análise, portanto, constatamos que o aluno, no Ensino Universal, é aquele que advinha o conhecimento por si mesmo, através da comparação incessante e da busca obstinada em dar resposta a tríplice questão do método da emancipação: o que vês? O que pensas disso? O que fazes com isso? Esforçando-se sempre por tornar-se um homem 
emancipado, razoável, crente de que tudo pode e aprendendo a linguagem própria daquilo que se propõe a aprender.

Esse aluno, já não se crê uma inteligência inferior àquela que o ensina, já não acredita na irrealidade da hierarquização da inteligência humana e, já não depende do mestre para compreender o que quer que seja, mas de si, de sua vontade, que o faz agir sem a necessidade de explicações, e de sua atenção que o faz buscar, incessante, as próprias respostas.

O mestre, no Ensino Universal, é um ignorante por convicção, jacta-se por ser assim, não se preocupa com o embrutecimento, sua única ocupação é a verificação devotada em comprovar a veracidade da opinião que sustenta a igualdade entre as inteligências e que sabe que não importa, em si, os meios que usa para comprová-la, os métodos e instrumentos, mas sim, acreditar na potência de seu aprendiz e exigir que este também se acredite e se comporte como homem razoável.

O mestre ignorante não subordina o entendimento do aluno à sua explicação, não reconhece a distância que mantém de um lado o mestre sábio e sua inteligência superior; e do outro, o aluno incapaz, com a inteligência inferior. Sabe perfeitamente que suas inteligências se diferenciam somente nas manifestações. Enfim, o mestre ignorante tem fé de que seu aluno pode tudo o que quiser. Pode compor uma bela música, mesmo sem conhecer a teoria musical. Pode se deleitar com a leitura de um poema e até escrever, sem a exigência de se tornar um extraordinário poeta. Pode ler e falar uma língua estrangeira sem a necessidade de dominar suas regras gramaticais.

$\mathrm{O}$ que faz o autor Jacques Rancière é declarar que o discurso da hierarquia de inteligências com todos os seus métodos e fundamentos, não é uma verdade a qual devemos seguir cegamente, mas uma opinião simplesmente. E que como ela, outra opinião existe, a da igualdade, esta deve ser verificada por cada homem em particular.

A aventura intelectual de Joseph Jacotot, narrada a partir de fatos observados por ele e que não passa de uma opinião sua, nos mostrou que a emancipação se baseia na igual estima de si e dos outros indivíduos. A crença na incapacidade que faz com que a inteligência se distraia e se abandone se inicia no desprezo de si como homem razoável que também significa desprezo dos outros homens, um desprezo que muitas vezes pode se passar por modéstia e incompetência. Ao declarar não saber, o ignorante está desprezando sua potência e a de seus semelhantes. Todo homem deve voltar-se a sua capacidade natural que o fez aprender tantas coisas sem mestre explicador.

A igualdade entre as inteligências depende da ação dos homens que individualmente ou em coletivo se aventuram a verificá-la. Cremos que aqueles que se dedicam a educação não podem estar alheios a esse debate mais que atual iniciado por Joseph Jacotot e reacendido por Jacques Rancière; pois mais do que um discurso pedagógico, este é um debate que representa a mais bela possibilidade de revolução pedagógica, filosófica e política da educação.

\section{Referências}

BINGHAM, C. BIESTA, G.J.J. e RANCIÈRE, J. Jacques Rancière: education, truth, emancipation. Continuum, 2010. ISBN 978-1-4411-9095-6 - ISBN 978-1-4411-3216-1.

GATTI, B. A. A construção da pesquisa em educação no Brasil. Brasília: Plano Editora, 2002. Cap. 1, p. 15-39.

LEAL, M. O mestre ignorante: cinco lições sobre a emancipação intelectual, de Jacques Rancière. Grupo de leitura em aprendizagem automática - FEUP. 09 de Maio de 
2008. Disponível em: <http://www.virose.pt/download/ranciere_curto.pdf> Acesso em: 03/jul./2014.

LUCINI, M. Fenomenologia hermenêutica: uma experiência metodológica. In BRETAS, S. A. e SOBRAL, M. N. (org.) Pesquisa em educação: Interfaces, experiências e orientações. mimeo.

OLIVEIRA, Y.D. A formulação do problema de pesquisa: considerações sobre uma experiência no âmbito da história da educação. In BRETAS, S. A. e SOBRAL; M. N. (org.) Pesquisa em educação: Interfaces, experiências e orientações. mimeo.

PIRES, M. N. s.v. "Aforismo", E-Dicionário de Termos Literários (EDTL), coord. de Carlos Ceia, ISBN: 989-20-0088-9, <http://www.edtl.com.pt>, consultado em 12-09-2013.

RANCIÈRE, J. O Mestre Ignorante: Cinco Lições sobre a Emancipação Intelectual. Tradução de Lílian do Valle. Belo Horizonte: Autêntica, 2013 (Coleção: Experiência e Sentido). ISBN 978-85-7526-045-6.

SKLIAR, C. Jacotot-Rancière ou a dissonância inaudita de uma pedagogia (felizmente) pessimista.Educação \& Sociedade [online]. 2003, vol.24, n.82, pop.cit., 229-239. ISSN 0101-7330. Disponível em <http://www.scielo.br/pdf/es/v24n82/a13v24n82.pdf> Acesso em: 2013.

SOBRAL, M. N. Interfaces da pesquisa em educação In BRETAS, S. A. e SOBRAL, M. N. (org.) Pesquisa em educação: Interfaces, experiências e orientações. mimeo.

VERMEREN, P.; CORNU, L.; BENVENUTO, A. Atualidade de O mestre ignorante. Educação \& Sociedade. [online]. 2003, vol.24, n.82, 185-202. ISSN 0101-7330. Disponível em<http://www.scielo.br/pdf/es/v24n82/a09v24n82.pdf> Acesso em: 2013.

\footnotetext{
${ }^{1}$ Professora Dra. do Departamento de Educação e do Programa de Pós-Graduação em Educação da Universidade Federal de Sergipe.

${ }^{2}$ Graduada em Pedagogia no Departamento de Educação da Universidade Federal de Sergipe.
}

${ }^{3}$ Escrever uma biografia sobre Jaques Rancière significa um grande desafio, pois, felizmente, goza de boa saúde e suas posições teóricas e políticas podem sofrer toda sorte de mudança. Apenas deixemos aqui alguns endereços eletrônicos disponíveis para consulta: <http://www.egs.edu/faculty/jacques-ranciere/>; http://blogs.artinfo.com/brazilnews/2012/10/04/jacques-ranciere-participa-de-coloquio-no-rio-de-janeiro/>; <http://en.wikipedia.org/wiki/Jacques_Ranci\%C3\%A8re>.

${ }^{4}$ Cf. ALTHUSSER. L. Ideologia e aparelhos ideológicos do Estado. Lisboa: Presença, 1974. BOURDIUE, P. e PASSERON, J. C. A reprodução. Elementos para uma teoria do sistema de ensino. RJ: Francisco Alves, 1975. ESTABLET, R. A escola. Revista Tempo brasileiro. RJ, p. 93 - 125. out/dez 1974.

${ }^{5}$ Para Rancière, Joseph Jacotot já havia experimentado seu próprio método. Ver página 32 da obra $O$ mestre ignorante (2013).

${ }^{6}$ As Aventuras de Telêmaco é uma releitura do épico de Homero escrita em 1699 por Fénelon. Disponível em:

$<$ http://www.madras.com.br/portal/index.php?page=shoop.cit.,product_details\&flypage=flypage.tpl\&product _id=655\&category_id=41\&option=com_virtuemart\&Itemid=40\&vmcchk=1\&Itemid=40>Acesso em: 29/mai./2014

${ }^{7}$ Em alguns trechos da obra, Jacques Rancière se refere ao fundador do Ensino Universal como louco. Ver página 43 da obra $O$ mestre ignorante (2013).

${ }^{8}$ Como poeta dramático, Jean-Baptiste Racine é um dos maiores autores da literatura francesa. Mais informações em: <http://educacao.uol.com.br/biografias/racine.jhtm>.

Recebido: julho-15 Aprovado: agosto-15 